(Житомирський державний університет імені Івана Франка) valerakontsedailo@gmail.com ORCID: 0000-0002-6463-370X

\title{
РОЗРОБКА МОДЕЛІ ВИКОРИСТАННЯ ІГРОВИХ СИМУЛЯТОРІВ ДЛЯ ФОРМУВАННЯ ПРОФЕСІЙНИХ КОМПЕТЕНТНОСТЕЙ МАЙБУТНІХ ІНЖЕНЕРІВ-ПРОГРАМІСТІВ
}

Запропоновано авторську модель використання ігрових симуляторів для формування професійних компетентностей майбутніх інженерів-програмістів. Представлено педагогічні підходи та приничипи навчання, традиційні та нетрадчційні форми організації навчання, запропоновано методи навчання та окреслено необхідні засоби навчання. Виділено критерії, відповідні показники та рівні сформованості професійних компетентностей.

Ключові слова: професійні компетентності, м'які компетентності, інженери-програмісти, ігрові симулятори.

Вступ. Переважна більшість інженерів-програмістів працюють у командах i для виконання поставлених завдань 3 розробки програмного забезпечення їм часто доводиться спілкуватися 3 технічними або нетехнічними співробітниками та клієнтами, а також поглиблено обговорювати 3 ними вимоги, дизайн та реалізацію замовленого програмного забезпечення. Саме тому компетентності міжособистісного спілкування, співпраці, роботи у команді та інші професійні м'які компетентності вкрай важливі для успішної професійної діяльності інженерів-програмістів.

Відповідно до багатьох наукових досліджень сформованість професійних м'яких компетентностей у інженерів-програмістів має значний вплив на успішний хід та завершення проектів розробки програмного забезпечення. Проте формуванню професійних м'яких компетентностей майбутніх інженерів-програмістів приділяється недостатньо уваги у навчальних програмах вищої школи, особливо у контексті практичних занять, навчальних проектів та професійної практики програмної інженерії. Як результат, багато майбутніх інженери-програмістів не визнають важливість спілкування і не володіють необхідними професійними м'якими компетентностями.

У той час, як більшість підходів до навчання майбутніх інженерів-програмістів спрямовані на додавання реалізму у практичні заняття в аудиторії, деякі науковці (М. Баррос, А. Бейкер, С. Вернер, А. Дантас, Е. Наварро, А. Хук) стверджують, що єдиним можливим способом надання студентам досвіду участі у реальних процесах розробки ПЗ в академічному середовищі є використання ігрових симуляторів та симуляцій у поєднанні з лекціями і навчальними проектами. Даний підхід має на меті дозволити студентам краще практикуватись і брати участь у процесах розробки ПЗ у більшому масштабі і більш швидким способом, ніж це може бути досягнуто на основі фактичних проектів.

Аналіз останніх досліджень і публікацій. Питання формування професійних компетентностей у майбутніх інженерів-програмістів тією чи іншою мірою розглядають у своїх роботах такі дослідники, як М. Арат, Ф. Ахмед, Е. Еспіноза, Е. Метсвені, М. Морган, Д. Ногуез, Д. Е. Пол, А. Ф. Сілва, Т. Хорне. Використання ігрових симуляторів для формування професійних компетентностей майбутніх інженерівпрограмістів у своїх працях підіймали Р. Атал, М. Баррос, А. Бейкер, С. Вернер, Д. Віл, К. Колфілд, С. П. Мей, Е. Наварро, А. Сурека, Ц. Ся, А. Хук та ін.

Метою нашої статті $\epsilon$ розробка моделі використання ігрових симуляторів для формування професійних компетентностей майбутніх інженерів-програмістів.

Узагальнення та систематизація наукової літератури дали можливість запропонувати авторську модель формування професійних компетентностей майбутніх інженерів-програмістів, що базується на використання ігрових симуляторів (див. рис. 1)

Запропонована модель враховує педагогічні підходи і принципи навчання та складається 3 мети, трьох структурних блоків i очікуваного результату. Метою $є$ формування професійних "м'яких" компетентностей майбутніх інженерів-програмістів.

У запропонованій моделі застосовуються такі педагогічні підходи:

- $\quad$ компетентнісний - спрямованість освітнього процесу на формування та розвиток ключових $\mathrm{i}$ предметних компетенцій особистості; передбачає орієнтацію всіх компонентів навчального процесу на здобуття майбутніми фахівцями компетенцій, необхідних для професійної діяльності [1: 11];

підходу діяльність визначають як основу, засіб і вирішальну умову розвитку особистості, як форму активної цілеспрямованої взаємодії людини з навколишнім світом [2: 123]; 


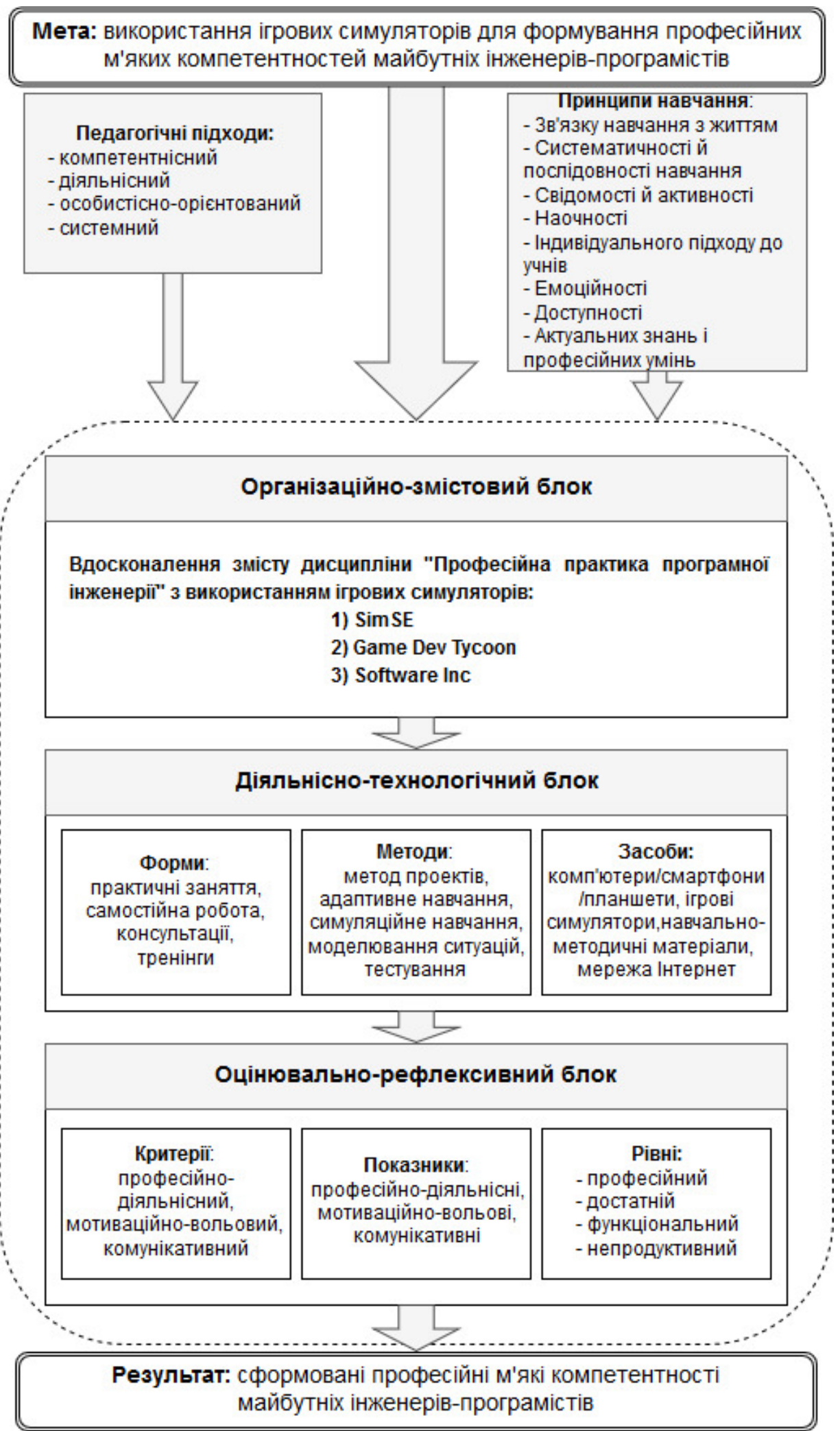

Рис. 1. Модель використання ігрових симуляторів для формування м'яких професійних компетентностей майбутніх інженерів-програмістів

- $\quad$ особистісно-орієнтований - всебічний розвиток особистості студента, а саме забезпечення умов розвитку особистості, реалізацію ії природних потенціалів. У процесі формування професійної компетентності майбутніх інженерів-програмістів особистісно-орієнтований підхід дозволяє вирішувати наступні задачі: 1) забезпечити кожному студенту можливість навчання з урахуванням його здібностей, інтересів та мотивів вивчення професійних дисциплін; 2) змінити погляди викладачів та студентів на їх 
роль та позиції в процесі формування професійних компетентностей; визначити необхідний характер міжособистісних взаємодій студента та викладача для підвищення ефективності даного процесу; 3) сприяти формуванню потреби в постійному самовдосконаленні в питаннях застосування професійних знань у майбутній професійній діяльності [2: 123];

- $\quad$ системний - розкриття цілісності педагогічних об'єктів, виявлення в них різноманітних типів зв'язків і зведення їх в єдину теоретичну картину; створює умови для послідовності та стабільності наукових пошуків [2: 124];

- $\quad$ ситуаційний підхід - направленість навчання на вироблення у студентів певного ставлення до діяльності та на формування реальної поведінки в певних ситуаціях [3: 203].

Використання даної моделі можливе лише з дотриманням таких принципів навчання:

- $\quad$ зв'язку навчання з життям - в основі цього принципу лежать об'єктивні зв'язки між теорією та практикою, а також між наукою та конкретним застосуванням знань. Теоретичні знання лежать в основі ефективної праці, яка у свою чергу сприяє удосконаленню вже наявних знань та навичок [4: 66];

- $\quad$ систематичності й послідовності навчання - цей принцип визначається логікою науки та особливостями пізнавальною діяльності учнів, яка залежить від вікових та індивідуальних особливостей розвитку [5: 19];

- $\quad$ свідомості й активності - цей принцип передбачає усвідомлений та творчий підхід до засвоєння знань. Варто зазначити, що усвідомлене засвоєння знань забезпечується роз'ясненням мети i завдань навчального предмета, його практичного значення у житті та перспектив; залученням у процес навчання мислительних операцій та критичного підходу; належним контролем та самоконтролем [4: 67];

- наочності - наочність поділяють на такі види в залежності від характеру відображення дійсності: натуральна, зображувальна, схематична [6: 150];

особливостей студентів, рівня їхнього розумового розвитку, знань та умінь, а також інтересів i працездатності, що дає змогу студентам в умовах колективного навчання по-своєму засвоювати навчальний матеріал [7: 54];

- емоційності - у процесі навчання у студентів виникає певне ставлення до предмету та емоційний стан, що покращує або погіршує засвоєння матеріалу [8];

- доступності - необхідною умовою продуктивного навчання $є$ відповідність його змісту, способів та методів віковим та індивідуальним особливостям студентів [9];

- $\quad$ актуальних знань $i$ професійних умінь - пов'язаний з визначенням у ВНЗ тих дисциплін 3 актуальних знань та вмінь, які повинні вивчати студенти, щоб одержані знання та вміння були вже сьогодні і завтра потрібні роботодавцям [10: 13].

У організаційно-змістовому блоці передбачається вдосконалення змісту дисципліни "Проектний практикум та професійна практика програмної інженерії" за допомогою впровадження та використання інформаційно-комунікаційних технологій, таких як: ігрові симулятори. Метою використання ігрових симуляторів у процесі викладання навчальної дисципліни "Проектний практикум та професійна практика програмної інженерії" $\epsilon$ формування у майбутніх інженерів-програмістів професійних компетентностей, пов'язаних з ефективною побудовою роботи у команді і комунікаціями у професійному контексті у рамках проектів розробки програмного забезпечення, оволодіння основами ефективної роботи 3 колегами та іншими зацікавленими сторонами (клієнтами, представники замовника, консультантами), концепціями співробітництва, стратегіями вислуховування, вирішення конфліктів, переконання та ведення переговорів, принципами ефективної усної комунікації, концепціями планування та пріоритезації свого часу та роботи, а також роботи під тиском.

Діяльнісно-технологічний блок передбачає систематичне удосконалення форм організації, методів та засобів навчання майбутніх інженерів-програмістів через впровадження симуляційного навчанням на основі інформаційно-комунікаційних технологій у поєднанні 3 практичними заняттями, тренінгами та лекціями.

Запропонована модель включає традиційні та нетрадиційні форми організації навчання, такі як: лабораторні роботи; практичні заняття; самостійна робота; менторство; консультації; тренінги; лекціябесіда; лекція-дискусія; проблемна лекція; тести; аудиторна модульна контрольна робота; іспит.

Застосовуються наступні методи навчання:

- $\quad$ метод проектів - метод навчання, що базується на включенні студентів у зміст тих чи інших проектів з метою розвитку творчих і пізнавальних навичок студентів, а також умінь орієнтуватися в інформаційному просторі, критично мислити і самостійно здобувати нові знання;

- $\quad$ адаптивне навчання - даний метод передбачає оцінювання початкової підготовки суб'єкта навчання та відстеження результатів проходження навчання, а також характеристики сприйняття нових відомостей, передбачає можливість індивідуального коригування параметрів, структури й алгоритмів навчання;

- $\quad$ симуляційне навчання - метод навчання, в основі якого лежить імітація будь-якого процесу за 
допомогою штучної системи. Для реалізації методу симуляційного навчання використовують штучно створене імітоване середовище для навчання, наприклад, симуляційні системи для відпрацювання конкретних практичних компетентностей або компетентностей командної роботи в конкретній імітованій ситуації;

- м моделювання ситуащій - метод навчання, основу якого становить використання завдань, що базуються на моделюванні професійних ситуацій, а також на знаходженні такого оптимального рішення проблеми, від якого у студентів загострюється професійний інтерес, відбувається актуалізація наявних знань, умінь, навичок та досвіду, формуються компетентності професійного аналізу та узагальнення, а також відбувається розвиток необхідних професійних компетентностей;

- $\quad$ тестування - науково обгрунтована форма процесу вимірювання знань студентів, що базується на застосуванні педагогічних тестів; допомагає визначити рівень знань та вмінь студентів, їх інтелектуальний розвиток за допомогою відповідно сформованих запитань, завдань, тестів та ін.

Також у діяльнісно-технологічному блоці виділені такі засоби навчання: комп'ютери / смартфони / планшети 3 доступом до мережі Інтернет, ігрові симулятори (прикладне ПЗ), навчально-методичні матеріали.

Оцінювально-рефлексивний блок містить рівні сформованості професійних компетентностей майбутніх інженерів-програмістів: професійний, достатній, функціональний, непродуктивний. Рівні визначається відповідно до критеріїв та показників сформованості професійних компетентностей, як інтегральний показник.

Виділяються наступні критерії сформованості професійних компетентностей:

- $\quad$ професійно-діяльнісний критерій - відображає ступінь розвитку професійних компетентностей організації процесу самовдосконалення та самоосвіти з метою професійного росту.

- мотиваційно-вольовий - відображає професійну спрямованість, мотивацію та наявність у майбутніх інженерів-програмістів особистісних якостей, які характеризують придатність до здійснення професійної діяльності.

- $\quad$ комунікативний критерій - полягає у здатності майбутніх інженерів-програмістів до міжособистісного та професійного спілкування; умінні демонструвати повагу у спілкуванні з кожним; спроможності встановлювати ділові контакти; умінні етично поводити себе у професійному середовищі 3 урахуванням культурних особливостей.

Професійно-діяльнісний критерій представлений такими ключовими показниками: майбутній інженер програміст:

- $\quad$ демонструє здатність до планування та пріоритезації;

- демонструє здатність до вирішення проблем;

- $\quad$ демонструє здатність до орієнтація на кінцевий результат

- демонструє здатність до звітності;

- демонструє здатність до професійної чесності та етики;

- демонструє здатність до інноваційності.

- демонструє здатність до вирішення проблем, а також організації та планування робочого процесу.

Мотиваційно-вольовий критерій представлений такими ключовими показниками: майбутній інженер-програміст

- $\quad$ демонструє здатність до мотивації, безперервного навчання та саморозвитку, ставить цілі та завдання у межах процесу самовдосконалення і розробляє відповідні кроки для їх реалізації;

- $\quad$ демонструє здатність до прийняття рішенні та здатний нести за них відповідальність;

- демонструє здатність до ініціативності;

- $\quad$ демонструє здатність адаптуватися до нових умов та обставин.

Комунікативний критерій представлений такими ключовими показниками: майбутній інженерпрограміст

- демонструє навички комунікативності, забезпечує чітку та ефективну комунікацію, а також бере на себе відповідальність за розуміння інших;

- демонструє навички міжособистісних відносин, розпочинає та підтримує ефективні відносини 3 іншими людьми; добре ставиться до людей іншого походження та у різноманітних ситуаціях; проявляє розуміння, ввічливість, тактовність, співпереживання, турботу та люб'язність; здатний до вирішення конфліктних ситуацій;

- демонструє здатність до роботи у команді, працює разом з іншими людьми та сприяє досягненню спільних поставлених цілей;

- демонструє здатність до співпраці, працює спільно з іншими, всередині та за межами організації, для досягнення цілей, що ведуть до створення і підтримки взаємовигідних 
партнерських відносин, максимально ефективного використання знань та досягнення відповідних результатів.

За допомогою зазначених критеріїв та компонентів були визначені рівні сформованості професійних компетентностей майбутніх інженерів-програмістів: професійний; достатній; функціональний; непродуктивний.

Зазначимо, що рівні сформованості професійних компетентностей майбутніх інженерів-програмістів пов'язані з критеріями та показниками сформованості професійних компетентностей наступним чином:

\begin{tabular}{|c|l|}
\hline Професійний & \multicolumn{1}{|c|}{ Показники всіх критеріїв наявні. } \\
\hline Достатній & $\begin{array}{l}\text { Рівень співвідноситься з наявністю показників хоча б трьох } 3 \\
\text { означених критеріїв на достатньому рівні або вище. }\end{array}$ \\
\hline Функціональний & $\begin{array}{l}\text { Показники двох або більше означених критеріїв є певним } \\
\text { чином наявними, проте не на достатньому рівні. }\end{array}$ \\
\hline Непродуктивний & $\begin{array}{l}\text { Показники двох або більше критеріїв вказують на } \\
\text { непродуктивний рівень. }\end{array}$ \\
\hline
\end{tabular}

Розглянемо узагальнено вище зазначені рівні сформованості професійних компетентностей майбутніх інженерів-програмістів.

Професійний рівень має відмінності у сформованості стійких професійних якостей та домінуванні професійно-моральних ціннісних орієнтацій. Просліджується чітке уявлення про сформованість індивідуального стилю професійної діяльності, прагненням до постійного професійного самовдосконалення та конструктивного вирішення проблем. Характеризується професійною спрямованістю, усвідомленим, позитивним ставленням майбутнього інженера-програміста до професійної діяльності, у тому числі до роботи у команді. Студент володіє глибокими, системними, усвідомленими знаннями, вміннями. Рівень самооцінки досить високий, рефлексивна позиція пов'язана 3 самоактуалізацією та самокритичністю у прийнятті власних рішень, виокремлюється понад все здатність працювати у команді. Студенти займаються пошуком особистісного змісту, як найважливішого прояву індивідуального стилю діяльності. Вільне застосування ІКТ та спецтехнологій у комунікаційному просторі, високий культурологічний та соціальний потенціал виконання професійних обов'язків та покладених повноважень зміцнює соціолого-психологічний та мотиваційно-вольовий компоненти професійних м'яких компетентностей, тим самим балансуючи сформованість та наближення професійної підготовки майбутніх інженерів-програмістів до рівня професіоналізму висококваліфікованого працівника, фахівця у своєї справі.

Достатній рівень виокремлюється достатнім проявом командного стилю професійної діяльності майбутнього інженера-програміста; цілеспрямованістю, усвідомленням основних ідей і понять про оволодіння професійними знаннями та вміннями; чітким усвідомленням своїх майбутніх повноважень і компетентностей; прагненням до внеску коректив у роботу, що виконується, вирішенням проблем та вдосконаленням окремих елементів праці, самостійністю у прийнятті рішень у невизначених умовах та перенесення знань, умінь та навичок у нові ситуативні позиції. Тобто усунення шаблонності вирішення професійних питань та висунення власних спроб урегулювати ту чи іншу виробничу ситуацію осмисленими і доцільними діями, бажання удосконалити свою фахову діяльність пошуком нових способів, методів та технологій; комунікативністю всередині команди та активною участю у різноманітних професійно-спрямованих заходах. Рефлексивна позиція пов'язана з самоствердженням, самореалізацією через формування індивідуального стилю, але є перспективи щодо професійного зростання через вдосконалення всіх існуючих компонентів формування професійних м'яких компетентностей майбутнього інженера-програміста в аспекті розвитку та інноваційності застосування сучасного та спеціалізованого програмного забезпечення у професійній діяльності.

Функціональний рівень засвідчується епізодичними знаннями про майбутню професійну діяльність інженерів-програмістів, визначається недостатнім пізнавальним інтересом до професії. Спостерігається слабка комунікативність та низька ефективність при роботі у команді. У вирішенні проблем орієнтованих на розумову i усвідомлюючу рефлексію мети майбутньої професійної діяльності допускаються значні помилки, що важко і невдало виправляються навіть на основі наслідування або інструкцій. При вирішенні складних і творчих вправ студенти уникають прийняття рішень, тобто прояв креативної та мобільної активності майбутнього інженера-програміста взагалі обмежується лише відтворювальними діями, не спостерігаються ознаки стійкого власного стилю діяльності, когнітивні та комунікативні компоненти професійних м'яких компетентностей майбутнього інженера-програміста знаходяться на елементарному рівні сформованості.

Непродуктивний рівень охарактеризований низьким мотиваційно-вольовим компонентом та невизнанням студента себе як особистості у майбутній професійній діяльності. Тобто, спостерігається повна невідповідність своєї майбутньої посади, відсутність здатності до виконання обов'язків, вирішення професійних проблем та опанування низкою повноважень, що покладаються роботодавцем на відповідного фахівця. Студенти володіють лише окремими вміннями на рівні простих операцій, при 
виконанні яких допускають значні помилки. Рефлексивна позиція присутня дуже рідко, характеризується нестійкістю, короткотривалістю та ситуативністю. Також, елементарний рівень теоретичної підготовки студентів визначається невмінням швидко і вчасно приймати самостійні рішення. У цьому сенсі 3 професією не пов'язані ціннісні орієнтації. Компетентності міжособистісного спілкування не відповідають кваліфікаційним вимогам до працівника даної кваліфікації. Слабко розвинені компетентності роботи в команді, студенти не виявляють стійкого інтересу до їх ефективного використання у процесі професійної підготовки та у майбутній професійній діяльності. Когнітивні компетентності розвинені на низькому рівні: студенти неспроможні швидко орієнтуватися у великих обсягах даних та відомостей, відчувають труднощі в їх пошуку і використанні.

Висновки та перспективи подальшого дослідження. Варто зазначити, що результатом моделі $\epsilon$ сформовані професійні м'які компетентності майбутніх інженерів-програмістів. Перевагами запропонованої авторської моделі є орієнтація навчально-виховного процесу на надання студентам досвіду участі у реальних процесах розробки програмного забезпечення в академічному середовищі та відповідність сформованих професійних компетентностей майбутніх інженерів-програмістів потребам ринку праці. У подальших дослідженнях планується виконати педагогічне проектування методики застосування ігрових симуляторів для формування професійних компетентностей майбутніх інженерівпрограмістів.

\section{СПИСОК ВИКОРИСТАНИХ ДЖЕРЕЛ ТА ЛІТЕРАТУРИ}

1. Литвин Т. Компетентнісний підхід у системі вищої освіти України: аналіз базових понять / Т. Литвин // Педагогіка і психологія професійної освіти. - 2012. - № 2. - С. 9-14.

2. Кучерук О. Методологічні підходи формування математичної компетентності майбутніх інженерівпрограмістів / О. Кучерук // Науковий вісник Ужгородського національного університету. Серія : Педагогіка. Соціальна робота. - 2016. - Вип. 2. - С. 122-125. - Режим доступу: http://nbuv.gov.ua/UJRN/Nvuuped_2016_2_32.

3. Шевчук О. Б. Основні підходи до підготовки майбутніх фахівців фінансово-економічного напряму в Україні / О.Б. Шевчук // Науковий вісник Мелітопольського державного педагогічного університету. Серія : Педагогіка. - 2013. - №. 2. - С. 200-207. - Режим доступу : http://nbuv.gov.ua/UJRN/Nvmdpu_2013_2_34.

4. Шевченко А. І. Методика навчання художнього проектування майбутніх фахівців з дизайну : дис. канд. пед. наук : 13.00.02 / Шевченко Анна Ігорівна - Київ, 2017. - 351 с.

5. Бущак Г. А. Розроблення тестових завдань та їх застосування для підсумкового контролю знань студентів 3 гуманітарних дисциплін: аналіз досвіду / Г. А. Бущак // Вісник Національного університету "Львівська політехніка". - 2012. - № 731 : Інформатизація вищого навчального закладу. - С. 18-22.

6. Комар О. А. Комплексний екзамен з окремих методик початкової освіти : навчально-методичний комплекс до державної атестації / О. А. Комар, Т. Я. Грітченко, Т. А. Торчинська,I. В. Шевчук. - Умань : ФОП Жовтий, 2016. - 183 с.

7. Давидюк М. О. Теорія і практика вищої професійної освіти: навчальний посібник / Укл. : М. О. Давидюк. Вінниця : ТОВ "Нілан ЛТД", 2015. - 94 с.

8. Кольбух Р. Суть принципу емоційності навчання та умови його реалізації [Електронний ресурс] / Роман Кольбух, Раїса Пріма. - $\quad$ Режим доступу: http://library.udpu.org.ua/library_files/psuh_pedagog_probl_silsk_shkolu/13/visnuk_13.pdf. - Назва $з$ екрану.

9. Фіцула М. М. Педагогіка вищої школи: навч. посіб / М. М. Фіцула. - К. : Академвидав, -2006. - 352 с. Режим доступу : http://pidruchniki.com/1613030534943/pedagogika/pedagogika. - Назва з екрану.

10. Дмитренко Г. А. Дворівнева модель підвищення якості вищої освіти в Україні. / Г. А. Дмитренко, С. В. Мудра, А. С. Спіцина // Актуальні проблеми педагогіки, психології та професійної освіти. - 2016. № 1. - C. 10-16.

\section{REFERENCES (TRANSLATED \& TRANSLITERATED)}

1. Lytvyn T. Kompetentnisnyi pidkhid u systemi vyshchoi osvity Ukrainy : analiz bazovykh ponyat' [Competency Approach in the Higher Education System of Ukraine : An Analysis of Basic Concepts] / T. Lytvyn // Pedahohika i psykholohiia profesinoi osvity [Pedagogy and Psychology of Vocational Education]. - 2012. - № 2. - Pp. 9-14.

2. Kucheruk O. Metodolohichni pidkhody formuvannia matematychnoi kompetentnosti maibutnikh inzhenerivprohramistiv [Methodological Approaches to the Formation of Mathematical Competence of Future Engineer Programmers] / O. Kucheruk // Naukovyi visnyk Uzhhorods'koho natsional'noho universytetu. Seriia : Pedahohika. Sotsial'na robota [Scientific Bulletin of Uzhgorod National University. Series : Pedagogy. Social work]. - 2016. Vyp. 2. - P. 122-125. - Rezhym dostupu : http://nbuv.gov.ua/UJRN/Nvuuped_2016_2_32.

3. Shevchuk O. B. Osnovni pidkhody do pidhotovky maybutnikh fakhivtsiv finansovo-ekonomichnoho napriamu $\mathrm{v}$ Ukraini [The Main Approaches to the Training of Future Specialists in the Field of Finance and Economics in Ukraine] / O. B. Shevchuk // Naukovyi visnyk Melitopol's'koho derzhavnoho pedahohichnoho universytetu. Seriia: Pedahohika [Scientific Bulletin of the Melitopol State Pedagogical University. Series : Pedagogy]. - 2013. - № 2. P. 200-207. - Rezhym dostupu : http://nbuv.gov.ua/UJRN/Nvmdpu_2013_2_34.

4. Shevchenko A. I. Metodyka navchannia khudozhn'oho proektuvannia maybutnikh fakhivtsiv z dyzainu [Method of Teaching Artistic Designing of Future Design Specialists] : diss. kand. ped nauk: 13.00.02/ Shevchenko Anna Igorivna. - Kyiv, 2017. - 351 p. 
5. Bushchak G. A. Rozroblennia testovykh zavdan' ta yikh zastosuvannia dlia pidsumkovoho kontroliu znan' studentiv z humanitarnykh dystsyplin : analiz dosvidu [Development of Test Tasks and Their Application for Final Control of Students' Knowledge in Humanities : an Analysis of Experience]/ G. A. Bushchak // Visnyk Natsional'noho universytetu "L'vivs'ka politekhnika" [Bulletin of the National University "Lviv Polytechnic"]. - 2012. - № 731 : Informatyzatsiya vyshchoho navchal'noho zakladu [Informatization of Higher Educational Institution]. - P. 18-22.

6. Komar O. A. Kompleksnyi ekzamen z okremykh metodyk pochatkovoyi osvity : navchal'no-metodychnyy kompleks do derzhavnoyi atestatsiyi [Complex Exam on Separate Methods of Elementary Education : Educational-methodical Complex for State Attestation] / O. A. Komar, T. Ya. Gritschenko, T. A. Torchinskaia, I. V. Shevchuk. - Uman' : FOP Yellow, 2016. - 183 p.

7. Davydiuk M. O. Teoriia i praktyka vyshchoyi profesinoi osvity [Theory and Practice of Higher Professional Education] : [navchal'nyy posibnyk]. - Vol. : M. O. Davidiv. - Vinnytsia : TOV "Nilan LTD", 2015. - 94 p.

8. Kolbukh R. Sut' pryntsypu emotsiinosti navchannia ta umovy yoho realizatsii [The Essence of the Principle of Emotional Learning and the Conditions for Its Implementation] [Elektronnyi resurs] / R. Kolbukh, R. Prima. - 2015. - Rezhym dostupu : http://library.udpu.org.ua/library_files/psuh_pedagog_probl_silsk_shkolu/13/visnuk_13.pdf. Nazva z ekranu.

9. Fitsula M. M. Pedahohika vyshchoi shkoly [Pedagogy of the Higher School] : [navch. posib.] / Fitsula M. M. - K. : $\begin{array}{llllllll}\text { Akademvydav, } & - & 2006 . & - & 352 & \text { p. } & - & \text { Rezhym }\end{array}$ http://pidruchniki.com/1613030534943/pedagogika/pedagogika. - Nazva z ekranu.

10. Dmitrenko G. A. Dvorivneva model' pidvyshchennia yakosti vyshchoyi osvity v Ukraini [Two-Level Model for Improving the Quality of Higher Education in Ukraine] / G. A. Dmitrenko, S. V. Mudra, A. Ye. Spitsina // Aktual'ni problemy pedahohiky, psykholohii ta profesiinoi osvity [Actual Problems of Pedagogy, Psychology and Professional Education]. - 2016. - № 1. - P. 10-16.

\section{Концедайло В. В. Разработка модели использования игровых симуляторов для формирования профессиональных компетентностей будущих инженеров-программистов.}

Предложена авторская модель использования игровых симуляторов для формирования профессиональных компетентностей будущчих инженеров-программистов. Представлены педагогические подходы и принциипы обучения, традиционные и нетрадиционные формы организации обучения, предложены методы обучения и намечены необходимые средства обучения. Выделены критерии, соответствующие показатели и уровни сформированности профессиональных компетентностей.

Ключевые слова: профессиональные компетентности, мягкие компетентности, инженерыпрограммисты, игровые симуляторы.

\section{Kontsedailo V. V. The Development of the Model of Use of Simulation Games to Develop Professional Competencies of Future Software Engineers.}

The development of professional soft competencies of future software engineers plays an important role in the curricula of software development education, especially in the context of practical exercises, educational projects and professional practice. The author's model that describes the use of simulation games to develop professional competencies of future software engineers is proposed. The following pedagogical approaches are presented: competence-based, activity-based, personality-oriented, systematic and situational. Such principles of teaching are considered: the connection of learning with life, the systematic and consistent training, principles of consciousness and activity, visibility, the individual approach, principles of emotionality, accessibility, the principle of relevant knowledge and professional skills. The following traditional and non-traditional forms of the organization of teaching are presented: laboratory works, practical lessons, independent work, mentoring,

consultations, trainings, lecture-conversation, lecture-discussion, problem-based lecture, tests, modular assessments, exams. The following teaching methods are considered: project based learning, adaptive learning, simulation-based learning, situation-based learning, assessment based learning. The use of such teaching aids is

defined: computers, smart phones, tablets with access to the Internet, simulation games and educational materials. The following criteria for the development of professional competencies and key indicators for each one of them are defined: professional and activity-based, motivational, functional, communicative. The following levels of professional competencies of future software engineers are defined: professional, sufficient, functional, and unproductive. The outcome of the model is the developed professional soft competencies of future software engineers. The advantages of the proposed model are the focus of the educational process on providing students with the experience of participating in real software development processes in an academic environment and the orientation on matching the developed professional soft competencies of future software engineers with the demands of the labor market.

Key words: professional competence, soft competence, software engineers, simulation games. 